UNIVERSITY OF CHITRAL JOURNAL OF LINGUISTICS AND LITERATURE VOL. 5 | ISSUE II | JULY - DEC | 2021 G $=\mathbb{1}$ IS ISSN (E): 2663-1512, ISSN (P): 2617-3611

https://doi.org/10.33195/ill.v5ill.310

\title{
A Corpus-based Study of Analyzing the Lexical Specificity in the Preface Section of the Selected Pakistani Academic Textbooks
}

\author{
Sadia Choudhri \\ MPhil Scholar, Department of English, Air University Islamabad \\ Dr. Tehseen Zahra \\ Assistant Professor, Department of English, Air University Islamabad \\ Dr. Wasima Shehzad \\ Professor, Department of English, Air University Islamabad
}

\begin{abstract}
A preface is the author's endeavor to describe the text and indicates why the text has been written. It also underlines some of the author's references and the text's relevant point of concern. Thus, the preface functions as the author's introduction to the book. It is the section of the book in which the authors guide the reader about the text and share their opinions and beliefs on the text's content. Due to the importance of prefaces in textbooks, the present study attempts to explore the linguistic specificity in the preface section of the Pakistani academic soft discipline textbooks at Higher Secondary School Certificate (HSSC) and Bachelor's level. As specificity in writing is a crucial concept in using English for academic purposes. In a mix-method study, we have used the quantitative method (statistical percentage) in which the frequency along with percentage is recorded and further qualitatively interpreted with the help of concordance lines via AntConc software. The data of this study is compiled with the assistance of text fixer and file converter software. For the analysis of the corpus, Ken Hyland's (2009) model of lexical Specificity is adopted. The self-mention and hedges categories of the lexical specificity model have been analyzed for the preface section. The findings showed that there has been frequent use of the firstperson pronoun 'I and we' to build the authorial stance in the preface section. Further, the hedges like 'will and would' used in the preface section of the textbooks manifested the positive attitude of the authors by establishing solidarity for their readership and increasing the communicative tendency of the text. Thus, it is concluded that the preface of soft sciences textbooks would act as the mean with having dual communicative purposes, either to present the book and to publicize it to the potential readers.
\end{abstract}

Keywords: specificity, preface, self-mention and hedges, soft discipline textbooks 
UNIVERSITY OF CHITRAL JOURNAL OF LINGUISTICS AND LITERATURE VOL. 5 | ISSUE II | JULY - DEC | 2021 G $=$ = IIf ISSN (E): 2663-1512, ISSN (P): 2617-3611

https://doi.org/10.33195/Ill.v5ill.310

\section{Introduction}

Textbook plays an influential role throughout academia. It is basically a lengthy piece of writing and comprised of a long period of extensive research to contribute to the originality in the field of knowledge. In addition, it also provides the guiding principles for the students, teachers, and scholars. Academic textbooks are further comprised of many disciplines which include hard sciences (biology, chemistry, and physics) and soft sciences (economics, law, education, history linguistics). The members of the specific discipline are responsible for constructing a world view and developing unique modes of discourse (Bruffee, 1986; Wells, 1992; Hyland, 2012). Some disciplines are based on investigating the physical world that includes the health sector while other disciplines require the systematic view of the society in terms of language, cultural and historical perspective.

Different sections are incorporated within the academic textbooks which serve as the gateway to the book. These are the introductory section and the main content of the books. The introductory section includes many subcategories as forewords, preface, introductions, and acknowledgments. Thus, a textbook is qualified as an academic genre that provides the credited facts. Typically, academic textbooks are considered to have a peripheral position and are spotted as commercial undertakings (Hyland, 2004). Furthermore, Swales (1995) stated that academic textbooks require not to be discarded from the study of the genre as it provides the applicable research findings, incorporate new research findings, and introduce contemporary topics for study. Every text or genre has its own specific linguistic choices that need to be evaluated to uncover the communicative purpose of the specific genre or text. In this specific context, the preface section of the academic textbook has been selected to understand the specific lexical features employed in this part.

On this account, the 'specificity model' proposed by Hyland (2009) is used for the lexical specificity of the preface section. Specificity is a trait in the language that separates different referents (nouns) as is explicit to a particular context (Hyland, 2008). This notion further maintains that every language has some linguistic/lexical features and these features fluctuate in different genres. The same is true with disciplinary variation as each draws heavily on distinct lexical items, 
UNIVERSITY OF CHITRAL JOURNAL OF LINGUISTICS AND LITERATURE VOL. 5 | ISSUE II | JULY - DEC | 2021 G $=\mathbb{1}$ IS ISSN (E): 2663-1512, ISSN (P): 2617-3611

https://doi.org/10.33195/ill.v5ill.310

grammatical choices, and rhetorical features for creating unique specialized knowledge. Such as the discipline of science characterizes with technical vocabulary having mostly of specialist terms which explain the happening or existence of something in the world. The humanities discipline is accompanied by dictions related to abstraction. That leads from illustrations then moving to generalizations for the construction of more abstract versions of any events. Thus, the text is specific to discipline grounded on the marked lexical diversity of that domain (Prior, 1998; Hyland, 2002).

In the nutshell, the disciplinary variation is dependent on the community in which the specialists used a repertoire of literacy practices. Hence, the specialists are the skillful writers/authors who are thoughtful of their readers like any communicator. Accordingly, the writing is only considered to be successful if it is based on the appropriate understanding of professional context (Hyland \& Bondi, 2006). So the authors of the textbook used the colony of genres such as preface, forwards to communicate with readers directly about their attitudes and beliefs related to the text. Though college-level students come across with the blending of different academic subjects and it is sometimes problematic for them to find suitable textbooks of a specific discipline. Based on this, it is also hard to read the whole textbook before purchasing it. The only way of analyzing the quality of the competitive textbook is dependent on the effective preface section. It acts as a doorstep that inspires the reader's community and instigates the novice writers/authors towards developing the language sensitivity used in different academic genres such as preface. In order to realize the linguistics choices employed in the preface section of the textbooks the present study aims; to find out the common lexical features for self-mention and hedges used by Pakistani authors in the preface section of academic textbooks and to explore the specific lexical features for self-mention and hedges to understand the communicative purpose in the preface section of Pakistani academic textbooks.

\section{Literature Review}

Over the past few decades, a wide range of scrutiny of genre patterns and the schematic structure of textbooks have been recorded in cross-discipline with special consideration on the introductory section. Yet, the former studies in this area have been rather confined in extent 
UNIVERSITY OF CHITRAL JOURNAL OF LINGUISTICS AND LITERATURE VOL. 5 | ISSUE II | JULY - DEC | 2021 G $=\mathbb{1}$ IS ISSN (E): 2663-1512, ISSN (P): 2617-3611

https://doi.org/10.33195/ill.v5ill.310

because they concentrated on particular genres patterns. Thus, there appears to be scope for further exploring the introductory section of the textbooks with a particular focus on the preface. As the crucial task of textbook authors is to convince the potential audience to buy it. The humble way is to write an effective preface (introductory note) that aims to persuade the readers to buy a book. In Pakistan, English is regarded as a lingua franca, and it is used in almost all academia (Mackenzie, 2014). It is noteworthy to explore the Pakistani textbook written in the English language as it provides insight into the ways the English language is being modified by the authors (Aib \& Zahra, 2018). Therefore, this study is based on exploring the common lexical features used by the Pakistani authors and the specific lexical choices that assist to understand the communicative purpose of the preface section of the academic textbooks.

As evident from the previous studies, the textbook is a notable academic genre in a professional setting. On this ground, Swales (1995) asserts that the role of the textbook authors not only is to communicate with students but also to the audience in the professional domain who are concerned in evaluating the academic textbooks, they are inclined to write reviews about the textbooks and make a decision whether these textbooks are applicable in the classroom or not. He further extends his claims that academic textbooks are more dialogic as it establishes the interaction between evaluator-reader rather than with the consumer-reader. Thus, it seems that the textbook authors are tied up with the lucid nature of the writing task. This leads to the present study of concentrating on the textbooks' preface section at both the level of academic and promotional genre.

Textbooks' introduction entails many subcategories which include an introduction, preface, forward note, and acknowledgment. Among these, the textbook's preface provides a view of the books as a whole and also presents the promotional aspect (Bhatia, 1997, 2004). According to Bhatia (1997), textbooks' introductions and prefaces are both distinct categories. The introduction of the textbooks is informative while the preface of textbooks serves both the promotional and informative function. Thus, prefaces would act as the medium with dual communicative purposes, to present the book and to publicize it to the potential readers. As emphasized by Mohsenzadeh, "Prefaces are crucial because they enable the reader to gain an 
UNIVERSITY OF CHITRAL JOURNAL OF LINGUISTICS AND LITERATURE VOL. 5 | ISSUE II | JULY - DEC | 2021 G $=\mathbb{1}$ IS ISSN (E): 2663-1512, ISSN (P): 2617-3611

https://doi.org/10.33195/ill.v5ill.310

overview of the book, to get some information about the different sections of it, and therefore to determine which parts correlate to their aim in mind and thus worth to read" (2013, p.318). Regardless of this prominence, book prefaces are mostly under-researched.

Few studies have been conducted on the textbooks' preface as a persuasive genre. In one of the studies, Kuhi (2008) investigated a total of 21 textbooks prefaces and the textbooks were selected centered on writer experiences in order to study the pattern of move structure by applying Swale's analysis (1990). He identified four move structures i.e. purpose, audience, chapter introduction, and acknowledgment. Genre-related study of preface sections of the textbooks was further held by Azar (2012). He conducted the study on 22 prefaces in the field of linguistics and applied linguistics. By employing the Swales (1990) and Bhatia (1993) pattern of moves analysis, he pinpointed 4 moves pattern to construct a niche, establishing the orientation, sketch of chapters, and acknowledgment. This structural framework suggests the textual tactics manipulated by authors in order to approach their communicative goal. Another study on the move pattern of books prefaces was conducted by Abdollahzadeh and Salarvand, (2013). They explored the move patterns of book prefaces specifically in three distinct fields of study related to management, metallurgy, mathematics. They have taken 180 academic books from 2000-2011 respectively. They have further analyzed the frequencies of move and step in the corpus of the preface. According to this corpus-based study, there are no considerable differences between the three disciplines in terms of move structure, with reference to communicative purposes and readers' expectations. These studies revealed the fact that the textbook prefaces display both informational and promotional features. Hence, textbooks preface is a kind of metatextual genre that provides an interactive platform to manifest the real-time mediation in a discourse between participants which includes the readers and stakeholders.

In the context of Pakistan, textbooks play a vital role in teaching and learning resources that are used across the curriculum at the level of schools, colleges and universities. Just like in other countries, Pakistan also has designed a procedure to evaluate academic textbooks. There ought to be a consistent struggle and demanding research required for developing and producing one single piece of a textbook. The quality of the textbooks depends on the process of textbooks 
UNIVERSITY OF CHITRAL JOURNAL OF LINGUISTICS AND LITERATURE VOL. 5 | ISSUE II | JULY - DEC | 2021 G -1 II) ISSN (E): 2663-1512, ISSN (P): 2617-3611

https://doi.org/10.33195/ill.v5ill.310

evaluation that is based on field-testing. In Pakistan, the Ministry of Education (Curriculum wing) is responsible to devise and sanction the curriculum for the subjects till the intermediate level. The curriculum wing has been authorized to prescribe and remove any textual data which is inconvenient for students (Mahmood, Iqbal, \& Saeed, 2009). Although textbooks have a massive impact on what and how is education being imparted in primary, elementary, secondary, and higher secondary classes. Most teachers use textbooks as their first curriculum manual and thus receive paramount importance in Pakistani teaching domains. In developing countries, textbooks are considered as the only medium of information by the teachers. It has been revealed that textbook is the single accessible learning source in most educational institutions. Further materials as teaching audio-visual aids, additional reading e-books and school libraries are practically rare (Mahmood et al., 2009). The most renowned publishers in this respect include Dogars publishers, Auraq, Learners, Scholars and Global publications houses which produce academic books every year with revised editions. The present study is focused on the academic textbooks prefaces of social sciences at Higher Secondary School Certificate and undergraduate/Bachelors's level written by Pakistani authors.

Just like any genre, the preface genre also entails lexical choices which writers manifested through the specificity of diction in writing. Specificity is a tool that works in highlighting the specific lexical features of academic writing. In 2008, Hyland asserts that specificity in writing is a crucial concept in using English for academic purposes. His further findings reveal that within disciplinary specificity, there is a significant difference between soft and hard disciplines. For any specific purpose within a particular discourse community, the usage of language is governed by certain specific conventions. That is why all the discourse community depends on its unique characteristic features of communication. In order to understand the different linguistic features to identify and appreciate the language across disciplines, computer technology achieves a prominent role in which corpus-based analysis is noticeable. Within the Corpus-based analysis, corpus tools and corpora play a significant role when studies have been made in language learning. Many types of research are evident in the corpus-based analysis as Al-Zubaidi \& Jasim, (2016) conducted research on prefaces of linguistics books in two languages English and Arabic. Total 80 published 
UNIVERSITY OF CHITRAL JOURNAL OF LINGUISTICS AND LITERATURE VOL. 5 | ISSUE II | JULY - DEC | 2021 G $=\mathbb{1}$ IS ISSN (E): 2663-1512, ISSN (P): 2617-3611

https://doi.org/10.33195/ill.v5ill.310

books were selected from 1990-2010 (40 in English and 40 in Arabic). Frequencies and percentages were used to analyze the findings of this study. The findings demonstrated that the preface genre comprised of 9 move structures with some variation. This also revealed that the authors employed certain socio-cultural textual strategies as Islamic ideology in the Arabic corpus especially in the opening and closing move patterns.

The corpora analysis plays an important part in various fields such as English for academic purposes. It has paved the way to understand and closely examine the real-time instances of language usage patterns, the most frequent words/phrases in different disciplines or domains. These findings lead to identifying the particular genre. This is known as an evidence-based approach in EAP in which particular linguistic features are identified that are employed in specific discourse. One of the significant corpus-evidence-based studies is conducted by Hyland and this article is focused on the aim of making students familiar with the academic expressions or words which remove the hurdles in understanding the unknown text. The analysis of this study is based on exploring the frequency, collocation, and meaning of words in the Academic Word List from a multidisciplinary large corpus (2009). In Pakistan, corpus linguistic has got the focus of attention by scholars and researchers as it is an emerging field and many useful kinds of research have been performed. The genre-based corpus analysis of language specificity has also been the most prominent study among these. For instance, the study on specificity is conducted by Gul \& Khattak (2021), this is about the different linguistic choices that are frequently used in the ViceChancellors' messages on the universities' websites. Likewise, one of the studies in Pakistan was conducted to explore the features of academic verbs specificity used in the introductory part of Ph.D. dissertations in the domain of English studies (Khattak \& Shehzad, 2018).

Furthermore, one study is focused on lexical bundles used in academic textbooks. The findings showed a total of 102 lexical bundles that are frequently occurred in the selected Pakistani (Chemistry and Physics) textbooks and there was a prominence of referential expressions and discourse organizers in functional categories (Hussain, Zahra, \& Abbas, 2021). Thus, many studies have been conducted on academic articles, book reviews, academic lectures but the introductory section preface receives less attention from the researchers in Pakistan. Thus, the present research 
UNIVERSITY OF CHITRAL JOURNAL OF LINGUISTICS AND LITERATURE VOL. 5 | ISSUE II | JULY - DEC | 2021 G $=\mathbb{1}$ IS ISSN (E): 2663-1512, ISSN (P): 2617-3611

https://doi.org/10.33195/ill.v5ill.310

aims at viewing the lexical choices used by the Pakistani authors in the preface of the academic textbooks and their communicative functions. This study has investigated the following research questions:

1. What are the general lexical choices for self-mention and hedges employed by the Pakistani authors in the preface section of academic textbooks?

2. How do the specific lexical features used for self-mention and hedges show the communicative purpose in the preface section of Pakistani academic textbooks?

\section{Methodology}

The current study has adopted the corpus-based method to identify specific lexical choices prevailing in the preface section of Pakistani academic textbooks used in the soft sciences. A burgeoning area, the corpus-based study is theoretically a sophisticated approach in the present era. In it, the corpora are incorporated to test the hypothesis with the existing theories (Lindquist, 2018). Hence, the corpus is said to be a collection of text kept in an electronic device (Kennedy, 1991). For the execution of this study, we have used the mixed-method approach. As it has analyzed the frequencies with the percentage of lexical choices employed by textbooks authors and concordance lines for further clarity. The data for this research comprised of academic textbooks of social sciences prescribed at the Higher Secondary School Certificate (Henceforth HSSC) and undergraduate (Bachelor's degree in Arts) level.

The HSSC social sciences textbooks were selected as recommended by the 'Punjab Curriculum and Textbook Board, Lahore' and 'Khyber Pakhtunkhwa Textbook Board' in the colleges of Punjab and Federal. The academic textbooks at the undergraduate / Bachelor's degree in social sciences proposed by the Punjab University were also nominated as data for this study. There was a list of options provided to the students at both the HSSC and undergraduate / Bachelor's level and these were retrieved from the Higher Education Commission website. Although, these are considered to be optional subjects in academia. For the data of the current study, we have selected only those Pakistani textbooks which were widely used in the colleges of Rawalpindi and capital territory Islamabad colleges. For the said purpose, the convenience sampling technique was employed. The quality of the textbooks was based on the preferences 
UNIVERSITY OF CHITRAL JOURNAL OF LINGUISTICS AND LITERATURE VOL. 5 | ISSUE II | JULY - DEC | 2021 G $=\mathbb{1}$ IS ISSN (E): 2663-1512, ISSN (P): 2617-3611

https://doi.org/10.33195/ill.v5ill.310

based on the renowned publishers as Dogars, Unique series and Learners, etc. The social sciences textbooks include Economics (06), psychology (03), international relations (03), law (06), English (05), Islamiyat (03), women studies (03), education (03), journalism (03), public administration/ business studies (05), political science (03), civics of Pakistan (05) and sociology (02). Further, the details of the data are given in the appendix section with structural annotation. The lexical specificity in the preface section of Pakistani textbooks (social sciences) was extracted to use as data in this study. Three frequently occurring lexical items were selected from each category and further supported with the assistance of concordance lines retrieves from the corpus. For ethical consideration, this corpus is not published and shared by any regulatory bodies.

The present study is based on a few methodological limitations that the data consists of only the preface section of social sciences textbooks used in two major domains as HSSC and Bachelor's level. Many subjects of social sciences might not be part of the data due to a limited number of textbooks available in the marketplace. Lastly, the prefaces of the textbooks are not equal in number e.g., the textbooks of English and Islamiyat are considered from 'Khyber Pakhtunkhwa Textbook Board', the textbooks of Law, English Jurisprudence, Business communication and functional English from Punjab University. The maximum count for each subject taken for the prefaces of social sciences textbooks is three in number. The results of this study are taken into consideration in the light of available data.

Furthermore, there has been inaccessibility of soft copies of the selected textbooks and due to this, the preface section of the textbooks was copied from images. These images were transformed into Microsoft office MS Word 2013. These files were then handled through the Textfixer software for data cleaning which includes removing extra spaces in between lines and paragraphs. The Text-fixer software is available online and is freely accessible (https://www.textfixer.com). Then the clean Microsoft word files were converted and further passes through the file converter in order to make text files with free online source (https://www.online-convert.com). Afterward, when the desired Text files were attained then they were uploaded on AntConc version 3.5.9 (Windows) 2020 for the extraction of specific linguistic choices used by the authors of the social sciences. The data analyzes of this study was centered on 
UNIVERSITY OF CHITRAL JOURNAL OF LINGUISTICS AND LITERATURE VOL. 5 | ISSUE II | JULY - DEC | 2021 IIf ISSN (E): 2663-1512, ISSN (P): 2617-3611

https://doi.org/10.33195/Ill.v5ill.310

the 'specificity model' by Hyland (2009). The lists of Keywords belonging to the lexical specificity proposed by Hyland (2009) were considered. Only two of the categories were taken into account for the analyses of the data as Self-mention and Hedges. The frequencies were analyzed and then the concordance lines were interpreted accordingly.

Table 1: Composition of the Corpus of Pakistani Social Science Textbooks

\begin{tabular}{|l|l|l|l|}
\hline Total files & Types & Tokens & Corpus Software \\
\hline 50 & 3196 & 18029 & AntConc 3.5.9 \\
\hline
\end{tabular}

Table 1 explains that the preface section of 50 different social sciences textbooks was taken with word types 3196 and word tokens 18029. AntConc software (Anthony, 2020) was adopted, for the recording of frequencies and analysis of concordance lines.

\subsection{Theoretical Framework}

The present study has focused on the language specificity items proposed by Hyland (2009). Specificity to language is the crucial aspect with regard to analyzing discourse and language teaching. Hyland (2009), draws a clear distinction among the two broad categories of disciplines as hard and soft sciences. Every discourse has a specific communicative event that can be achieved only through lexical specificity. These conventions help the readers to identify the unique characteristics of the specific domain of discipline they are involved. In order to clearly understand the lexical specificity of soft and hard sciences Hyland (2009) devised a list that consists of different categories with linguistics items as listed below:

Table 2: Lexical Specificity Model by Hyland (2009)

\begin{tabular}{|l|l|}
\hline Lexical specificity & \multicolumn{1}{|c|}{ Definition } \\
\hline Self-mention & $\begin{array}{l}\text { The representation of the authorial self (Wu et al., } \\
\text { 2014) e.g. I, We, Me, etc. }\end{array}$ \\
\hline Hedges & $\begin{array}{l}\text { The manifestation of words or phrases in a } \\
\text { sentence that indicate the probability, e.g. can, } \\
\text { would, like, etc. (Hyland, 1994). }\end{array}$ \\
\hline Directives & $\begin{array}{l}\text { The words that usually direct the readers to } \\
\text { execute some action e.g. ought, could, might, etc. }\end{array}$ \\
\hline
\end{tabular}


UNIVERSITY OF CHITRAL JOURNAL OF LINGUISTICS AND LITERATURE VOL. 5 | ISSUE II | JULY - DEC | 2021 G -1 II) ISSN (E): 2663-1512, ISSN (P): 2617-3611 https://doi.org/10.33195/ill.v5ill.310

\begin{tabular}{|l|l|}
\hline Reporting Verbs & $\begin{array}{l}\text { to accomplish academic persuasion (Hyland, } \\
\text { 2002). }\end{array}$ \\
\hline Lexical Bundles & $\begin{array}{l}\text { The specific words that facilitate the writer to take } \\
\text { the responsibility of the argument being made } \\
\text { (Charles, 2006), e.g. say, develop, claim, etc. }\end{array}$ \\
\hline & $\begin{array}{l}\text { This category refers to reoccurring sequences of a } \\
\text { group of 3 or more words that exist together } \\
\text { (Biber et al., 2004), e.g. as well as, in the place of, } \\
\text { etc. }\end{array}$ \\
\hline
\end{tabular}


UNIVERSITY OF CHITRAL JOURNAL OF LINGUISTICS AND LITERATURE VOL. 5 | ISSUE II | JULY - DEC | 2021 G -1 II) ISSN (E): 2663-1512, ISSN (P): 2617-3611

https://doi.org/10.33195/ill.v5ill.310

Table 2 shows the different categories within the model of lexical specificity. as self-mention, hedges, directives, reporting verbs and lexical bundles. For this study, the lexical specificity developed by Hyland (2009) appears to be the most appropriate framework. The literature further supports this stance of using the framework (Khattak \& Shehzad, 2018; Gul \& Khattak, 2021). Therefore, to explore the specific linguistics features used in the preface section of the soft sciences academic books specificity model is adopted. The study is delimited to only focus on two domains of the specificity model such as self-mention and hedges. The rationale for selecting these two categories is that the authors mostly instilled the social and cultural influences through their voice (self-mention). Ultimately, in the case of textbooks, the authors are imparted promotional as well as informational prospects in the product to gain prominence in the marketplace. The categories of self-mention and hedges are highly prominent lexical specificity employed by the authors to achieve their desired target discourse. While the directives and reporting verb categories are linked to instruct the students towards interpreting and evaluating the learning content in text. Lastly, the lexical bundles are associated with the smooth cohesion of the text. In this regard, only those categories are considered which support to achieve the aims of this study.

\section{Data Analysis}

To address the research questions of the study, the converted text files are analyzed in AntConc 3.5.9 software. Self-mention and Hedge's list of lexical specificity were scrutinized for the present study.

\subsection{Self-Mention in Textbooks' Preface}

The first category introduced by Hyland (2009) in lexical specificity is the list of selfmention words. Self-mentioning is acting as the tool of authors to mention themselves in the written discourse with the help of certain usage of pronouns that assist to builds the argument. According to $\mathrm{Wu}$ et al. (2014), the lexis used for self-mentioning is a dominant rhetorical approach used to build an authorial stance in the research articles. He further posits that the researcher's authorial identity created by the voice or opinion of the authors is comprised of three features. For instance, the individual, the detached self and the mutual one, these three aspects depend on the type of self-mentioning pronouns used in the writing. 
UNIVERSITY OF CHITRAL JOURNAL OF LINGUISTICS AND LITERATURE VOL. 5 | ISSUE II | JULY - DEC | 2021 G $=\mathbb{1}$ IS ISSN (E): 2663-1512, ISSN (P): 2617-3611 https://doi.org/10.33195/ill.v5ill.310

Table 3: Self-Mentioning used in preface section of soft sciences academic textbooks

\begin{tabular}{|l|l|c|}
\hline Pronoun & Frequency & Percentage in corpus \\
\hline We & $\mathbf{7 0}$ & $\mathbf{0 . 3 8 \%}$ \\
\hline You & 10 & $0.05 \%$ \\
\hline I & $\mathbf{1 5 2}$ & $\mathbf{0 . 8 4 \%}$ \\
\hline Them & $\mathbf{3 7}$ & $\mathbf{0 . 2 0 \%}$ \\
\hline Us & 26 & $0.14 \%$ \\
\hline They & 30 & $0.17 \%$ \\
\hline Me & $\mathbf{5 2}$ & $\mathbf{0 . 2 8 \%}$ \\
\hline Mine & 01 & $0.005 \%$ \\
\hline
\end{tabular}

Table 3 reveals that the first prominent self-mentioning pronoun is the first-person singular pronoun "I" with the highest frequency of $152(0.84 \%)$. The details of concordance lines in the corpus show that the usage of pronoun "I" is frequent when the author presents his work as authentic to the readers.

- I have drawn heavily on the eminent scholars, past and present; and to all of them.

- I have utilized the innovations and methods employed by modern scholars of comparative politics.

- I have attempted to explain political premises in a way, I expect, as will help the students to understand the nature and significance of the political activity.

All these instances manifested the personal voice of the Pakistani authors which they use to establish the link towards the readability and show emotive attitude as well. "I" is used as 'individual self' in these examples (Wu et al., 2014). In addition, the highest percentage of ' $\mathrm{I}$ ' is based on other important aspects that is every author acknowledge the publisher and contributor of the books. For instance; 
UNIVERSITY OF CHITRAL JOURNAL OF LINGUISTICS AND LITERATURE VOL. 5 | ISSUE II | JULY - DEC | 2021 G -1 II) ISSN (E): 2663-1512, ISSN (P): 2617-3611 https://doi.org/10.33195/ill.v5ill.310

- I extend my heartiest felicitation and special thanks to those teachers and students.

- I acknowledge with deep gratitude the assistance.

- I am awfully grateful to my colleagues and friends for their invaluable suggestions.

The pronoun "me" as First-person is 52 times used with the percentage $0.28 \%$. The usage of "me" is associated with the authors and almost all the preface section demonstrate its usage.

- $\quad$ I am highly thankful to my friends and students who virtually wish me to write.

- $\quad$ The long drawn demand of English medium students and teachers urged me to write Psychology book for Intermediate level.

- My vast experience of competitive exams, together with the teaching experience, has enabled me to compile a comprehensive book.

Mostly it has been used either to take the responsibility of his endeavor of the task as an author or appreciative for the opportunity of writing a book. The next frequently used pronoun that appears in the preface section of social sciences textbooks is "we" with $70(0.38 \%)$ times. The first-person plural pronoun "we" manifested the mutual feelings of the authors which he intended to construct solidarity with the readers of the text. Certain verbs are associated with the pronoun "we" in order to achieve the communicative purpose.

- We have solemnly worked hard to extract the answers of the questions asked in competitive examination.

- We trust, both students of English Medium Schools and their teachers will find Islamiyat for students very useful in their respective tasks.

- We hope, would truly illumine fate for its users.

These emotive statements positively influence the reader to maintain readability by convincing them of their bright future. The pronoun "we" is represented as a "collective self" (Wu et al., 2014) in all these examples as it creates a harmony of the argument for the effect of generalization. The third highest frequency is the Third-person pronoun "them" with 37 (0.20\%). 
UNIVERSITY OF CHITRAL JOURNAL OF LINGUISTICS AND LITERATURE VOL. 5 | ISSUE II | JULY - DEC | 2021 G -1 II) ISSN (E): 2663-1512, ISSN (P): 2617-3611

https://doi.org/10.33195/ill.v5ill.310

The corpus analysis shows the demonstration of the pronoun "them" as "collective self" (Wu et al., 2014). For instance;

- The students' valuable comments and suggestions to enable me to serve them even better.

- I am also very much obliged to my university authorities (UOL) for providing me an opportunity to work for them in good academic environment.

- This book provides a blend of traditional approach, as well as, application of modern techniques to dig out the pertinent issues and in providing a practical approach to address them too.

Again, it provides the readers the sense of satisfaction about the quality of the textbooks and the future success in academia. In the third example, here the author need not bring propositional information rather they assist their readers in sorting, identifying, understanding, assessing, and responding to the content. Thus, self-mentioning lexical items in the text provide a platform for the writers to claim their work and express their stance to the prospective readers (Hyland, 2009).

The corpus analysis of the preface section of soft sciences textbooks shows the usage of first-person (singular) ' $\mathrm{I}$ ' is $0.84 \%$, first-person 'me' is $0.28 \%$, first-person (plural) 'we' is used $0.38 \%$ and third person 'them' is used $0.20 \%$. The significance of the representation of self by authors is through the individual and collective self in the preface section of the Pakistani social sciences textbooks.

\subsection{Use of Hedges in Textbooks' Preface}

The second category in the 'Lexical specificity model' is Hedges (Hyland, 2009). The functioning of Hedging is communicative and interactive in academic discourse by employing the purpose to heighten or lessen the intensity of assurance in the accuracy of given statements (Hyland, 2009). According to Salager Meyer (1994), the role of using hedging is to make the argument more fluid and adaptable. Hedges are the prominent lexical choices used to make the language of written discourse more indirect, polite and illustrate uncertainty in statements. It also shows the grammatical tense and aspect features in writing. Moreover, the usage of the hedges 
UNIVERSITY OF CHITRAL JOURNAL OF LINGUISTICS AND LITERATURE VOL. 5 | ISSUE II | JULY - DEC | 2021 G $=\mathbb{1}$ IS ISSN (E): 2663-1512, ISSN (P): 2617-3611

https://doi.org/10.33195/ill.v5ill.310

device provides the writers a platform where they prove that the claim made is not absolutely proven in order to lessen the effect of abrupt reaction of the reader. In addition, hedges perform a different function in the text as it is a more standardized pattern of academic writing and serves to have rhetorical impacts on the readers. It further establishes the opposing claims more politely so that these become productive for the potential readers. As Lakoff (1975), highlights that the diction used to manifest the hedges is to portray the claims more or less vague.

Table 4: Hedges used in preface section of soft sciences academic textbooks

\begin{tabular}{|l|l|r|l|r|r|}
\hline Hedge & Frequency & $\begin{array}{l}\text { Percentage in } \\
\text { corpus }\end{array}$ & Hedge & Frequency & $\begin{array}{l}\text { Percentage } \\
\text { in corpus }\end{array}$ \\
\hline That & $\mathbf{1 1 5}$ & $\mathbf{0 . 6 3 \%}$ & May & 29 & $0.16 \%$ \\
\hline Will & $\mathbf{7 7}$ & $\mathbf{0 . 4 2 \%}$ & Look & 04 & $0.02 \%$ \\
\hline Can & 31 & $0.17 \%$ & Should & 15 & $0.08 \%$ \\
\hline Would & $\mathbf{3 6}$ & $\mathbf{0 . 1 9 \%}$ & Must & 10 & $0.05 \%$ \\
\hline Believe & 05 & $0.027 \%$ & Possible & 10 & $0.05 \%$ \\
\hline About & 23 & $0.12 \%$ & Sure & 04 & $0.02 \%$ \\
\hline Like & 31 & $0.17 \%$ & Virtual & 00 & - \\
\hline
\end{tabular}

Table 4 shows the frequencies of all the Hedges included in the 'lexical specificity' model proposed by Hyland (2009). The highest frequency is 'That' with a percentage of $0.63 \%$. The analysis of corpus illustrates that the usage of 'That' is most frequently part of the complex sentences in which the authors of the book prefer to put it as a connector to refer to the previous chunk of information. The authors of the textbooks usually employ 'that' to keep the long information in a precise manner.

- International Relations, relatively a new discipline that appeared in the academic arena.

- The instant book is based on meticulous research that will enable the readers and students of IR to develop a terse. 
UNIVERSITY OF CHITRAL JOURNAL OF LINGUISTICS AND LITERATURE VOL. 5 | ISSUE II | JULY - DEC | 2021 G $=\mathbb{1}$ IS ISSN (E): 2663-1512, ISSN (P): 2617-3611

https://doi.org/10.33195/ill.v5ill.310

The convention of using "that-clause" ultimately reduces the abrupt reaction of readers and employs the rhetorical impact on them (Gul \& Khattak, 2021). Furthermore, "that" can be used after the reported verb in the clause. For instance;

- It is advised that each student make up a number of copies of this map.

- It is hoped that it would serve its purpose amicably and would help in the purification of society

This example shows that the author intended his reader to entail the action and suggest the 'subjective opinion' in a polite tone. Another example illustrates the usage of "that-clause" to begin the clause. Likewise;

- It is a fact that geography is neither a physical science, nor a social science, rather it combines the characteristics of both, and bridges the gap between the two.

- The reason is that there were a lot of books in this subject, and they were not in accordance with requirements of the prescribed syllabus.

This signifies that the authors used "that" to establish the credential related to the subject in a rhetorical manner. The rhetorical strategy is employed by the authors to locate the significance of the content present in the textbook. It further seizes the attention of the buyer which enhances the communicative tendency to publicize it among the stakeholders as well.

The usage of the modal verb 'will' with a percentage of $0.42 \%$ is prominent in the preface of soft sciences to show the concerns of the authors towards the bright future of the students.

- $\quad$ After reading it, the students will acquire a lot of confidence and will be able to solve the question paper easily in the examination.

- The technical jargon presented in this book will differentiate a layman writing from an expert and consequently will help in yielding more than average marks.

The examples of 'will' indicate that it is used to maintain a strong bond with the readers by providing a prosperous future. This shows the politeness strategy by the authors to make the claim more informative and develop the readership. The hedge "will" has also an implication of committing humbly which aids in their learning. 
UNIVERSITY OF CHITRAL JOURNAL OF LINGUISTICS AND LITERATURE VOL. 5 | ISSUE II | JULY - DEC | 2021 G -1 II) ISSN (E): 2663-1512, ISSN (P): 2617-3611

https://doi.org/10.33195/ill.v5ill.310

- Without being over-optimistic, I hope that the book will be of some useful help to those who are interested in learning about communication theory, business correspondence, report writing and other communication techniques.

- We hope that this book will enhance teaching and learning skills of the readers.

This is a positive assurance of the author towards his readers and it also engages the reader's attention to the main features of the textbook. This indicates the more informative aspects are shown with the help of "will". Another modal verb used in the preface section of the social sciences textbook is 'would' with a percentage of $0.19 \%$.

- This book resist the temptation to oversimplify world politics with a superficial treatment that would mask complexities and distort realities, it would prove a boon to our prospective students.

The usage of 'would' shows the soft tone to direct some kind of possibility to illumine the fate of the potential readers. It further highlights the inclination of the authors. For instance;

- $\quad$ The examples presented in the text are in the context of Pakistani society which would give students an additional benefit while taking the examination.

- In order to get at the essence of the subject, it would need right amount of dedication on the readers part.

Through this, the author shows his concerns towards readers and the students. The usage of "would" is a politeness strategy employed by most authors for the promotional perspective rather than being informative. The authors used the "would" to extent their gratitude in the preface section. It is deployed to motivate the contributor for the promotion of the textbook. Thus, these specific lexical items ultimately eradicate the remoteness between the readers and the author.

- I would like to extend my sincerest gratitude to all of the authors, writers, bloggers, individuals and organizations whose material - even a single word- was tapped.

On the whole, the result of the corpus further confirms the findings and affirms the list prosed by Hyland (2009). According to Hyland, There has been a large number of self-mention 
UNIVERSITY OF CHITRAL JOURNAL OF LINGUISTICS AND LITERATURE VOL. 5 | ISSUE II | JULY - DEC | 2021 G $=\mathbb{1}$ IS ISSN (E): 2663-1512, ISSN (P): 2617-3611

https://doi.org/10.33195/ill.v5ill.310

and hedges used in social sciences and Humanities as compared to Science and Engineering (2009). The corpus of the preface section of soft discipline shows that the authors used both the self-mention and hedges in a soft manner to influence their readership.

\section{Conclusion}

The results retrieved from the corpus of the present study show that the lexical specificity is prominent among Pakistani soft discipline authors while writing the textbooks. This study is delimited to only the preface section of the academic textbooks used in the colleges at the HSSC and undergraduate/ Bachelor's level. In addition, two lexical specificities as self-mention and hedges are taken into consideration while analyzing the data. The findings suggest that the selfmention pronouns which are frequent in the preface section include (I, me, we, and them). These self-mentioning lexical items indicate the representation of the author's identity as an individual and collective self (Wu et al., 2014). This further advocates that the author proposes his opinion or voice but by creating solidarity with the readers. The authors used the preface sections as an interactive platform with the pronoun 'we' to communicate with readers which also shows the dialogic nature of this platform (Swales, 1995). Then the use of Hedges like (that, will, would) indicates the author's attitude or feelings towards the readers. These lexical choices mark the specificity of communicative purpose which the authors achieve to establish a readership.

According to Hyland (1998), Hedges is marked in the written discourse to achieve the communicative function as these lexical categories are less direct and polite. The two specific categories as self-mention and Hedges used frequently by the authors in the preface section of the soft sciences textbook as the manifesto of the message being made. This also affirms that the lexical specificity belongs to self-mention and Hedges appears to present the positive portrayals of the textbook written by the expert authors. These positive linguistics choices help to influence the readers of the textbook and with the assistance of this, the informative and promotional aspects of the preface section are achieved (Bhatia, 1997, 2004; Gul \& Khattak, 2021). Thus, prefaces would act as the mean with having dual communicative purposes, either to present the book or to advertise it to the potential readers. In the Pakistani context, this study is significant in several ways as it reveals the textual devices used in the preface section with specific lexical features like 
UNIVERSITY OF CHITRAL JOURNAL OF LINGUISTICS AND LITERATURE VOL. 5 | ISSUE II | JULY - DEC | 2021 G $=\mathbb{1}$ IS ISSN (E): 2663-1512, ISSN (P): 2617-3611

https://doi.org/10.33195/ill.v5ill.310

self-mentioning ad hedges which manifest the social practices of authors as skillful participants of academic discourses. The outcomes of the research assist the college level students towards establishing disciplinary-specific repertoire with the help of which they can select the appropriate textbooks within a particular domain. It is also beneficial for novice writers to make the potential readership as the preface section is promotional and persuasive. Likewise, based on the current study, there can be ample choices for future researchers to investigate this specific domain of introductory sections of the academic textbooks. Moreover, the further direction will be to make a comparative analysis of both hard and soft discipline textbooks written by Pakistani authors is still needed to explore. Conclusively, all these researches promote the quality of the textbooks which improve the standard of academia in Pakistan.

\section{References}

Abdollahzadeh, E., \& Salarvand, H. (2013). Book prefaces in basic, applied and social sciences: A genre-based study. World Applied Sciences Journal, 28, 18-26

Aib, I., \& Zahra, T. (2018). Metadiscursive Practices: A Corpus-Based Study of Attitude Markers in Pakistani English Book Reviews: Attitude Markers in Pakistani English Book Reviews. CORPORUM: Journal of Corpus Linguistics, 1(1), 15-28.

Al-Zubaidi, N. A., \& Jasim, T. A. (2016). Preface Sections in English and Arabic Linguistics Books: A Rhetorico-Cultural Analysis. Advances in Language and Literary Studies, 7(2), 25-32.

Anthony, L. (2020). Lawrence Anthony’s Website. Retrieved from Lawrence Anthony's Website: https://www.laurenceanthony.net/software/antconc/

Azar, A. S. (2012). The self-promotion of academic textbooks in the preface section: A genre analysis. Atlantis, 34(2), 147-166.

Bhatia, V. K. (2004). Worlds of written discourse: A genre-based view. London: Continuum. 
UNIVERSITY OF CHITRAL JOURNAL OF LINGUISTICS AND LITERATURE VOL. 5 | ISSUE II | JULY - DEC | 2021 G $=\mathbb{1}$ IS ISSN (E): 2663-1512, ISSN (P): 2617-3611

https://doi.org/10.33195/ill.v5ill.310

Bhatia, V. K. (1997). Genre-mixing in academic introductions. English for specific purposes, 16(3), 181-195.

Biber, D., Conrad, S., \& Cortes, V. (2004). If you look at...: Lexical bundles in university teaching and textbooks. Applied linguistics, 25(3), 371-405.

Bruffee, K. A. (1986). Social construction, language, and the authority of knowledge: A bibliographical essay. College English, 48(8), 773-790.

Charles, M. (2006). Phraseological patterns in reporting clauses used in citation: A corpus-based study of theses in two disciplines. English for Specific Purposes, 25(3), 310-331.

Gul, H. \& Khattak, N. U. R. (2021). A Corpus-Based Genre Analysis of the Linguistic Specificity of VC Messages on the Websites of Universities in Pakistan. Erevna Journal of Linguistics and Literature, 4(2), 13-34.

Hussain, G., Zahra, T., \& Abbas, A. (2021). Discourse Functions of Lexical Bundles in Pakistani Chemistry and Physics Textbooks. GEMA Online® Journal of Language Studies, 21(1).

Hyland, K. (1994). Hedging in academic writing and EAF textbooks. English for specific purposes, 13(3), 239-256.

Hyland, K. (2002). Specificity revisited: How far should we go now?. English for specific purposes, 21(4), 385-395.

Hyland, K. (2004). Disciplinary discourses, Michigan classics ed.: Social interactions in academic writing. University of Michigan Press.

Hyland, K., \& Bondi, M. (Eds.). (2006). Academic discourse across disciplines (Vol. 42). Frankfort: Peter Lang.

Hyland, K. (2008). As can be seen: Lexical bundles and disciplinary variation. English for Specific Purposes, 27(1), 4-21.

Hyland, K. (2009). Writing in the disciplines: Research evidence for specificity. Taiwan International ESP Journal, 1(1), 5-22.

Hyland, K., \& Tse, P. (2009). Academic lexis and disciplinary practice: Corpus evidence for specificity. International Journal of English Studies, 9(2). 
UNIVERSITY OF CHITRAL JOURNAL OF LINGUISTICS AND LITERATURE VOL. 5 | ISSUE II | JULY - DEC | 2021 G $=\mathbb{1}$ IS ISSN (E): 2663-1512, ISSN (P): 2617-3611

https://doi.org/10.33195/ill.v5ill.310

Hyland, K. (2012). Disciplinary identities: Individuality and community in academic discourse. Cambridge: Cambridge University Press.

Kennedy, G. (1991). Between and through: The company they keep and the functions they serve. In K. Aijmer, \& B. Altenberg (Eds.), English Corpus Linguistics. London and New York: Longman.

Khattak, N. U. R., \& Shehzad, W. (2018). A corpus-based study of the specificity of academic verbs in introduction sections of Ph.D. dissertations in English studies in Pakistan. Dialogue XIV (1), 63-74.

Kuhi, D. (2008). An analysis of the move structure of textbook prefaces. Asian ESP Journal, 7 , 63-78.

Lakoff, G. (1975). Hedges: A study in meaning criteria and the logic of fuzzy concepts. In Hockney, D. J., Harper, W. L., \& Freed, B. (Eds.), Contemporary research in philosophical logic and linguistic semantics (pp. 221-271). Springer, Dordrecht.

MacKenzie, I. (2014). English, as a Lingua Franca: Theorizing and teaching English. London: Routledge.

Lindquist, H. (2018). Corpus linguistics and the description of English. Edinburgh University Press.

Mahmood, K., Iqbal, M. Z., \& Saeed, M. (2009). Textbook evaluation through quality indicators: The case of Pakistan. Bulletin of Education and Research, 31(2), 1-27.

Mohsenzadeh, H. (2013). Rhetorical move structure of literature book prefaces in English and Persian. Mediterranean Journal of Social Sciences, 4(4), 317.

Prior, P. (1998). Writing/disciplinarity: A sociohistoric account of writing in the disciplines.Hillsdale, NJ: Lawrence Erlbaum.

Salager-Meyer, F. (1994). Hedges and textual communicative function in medical English written discourse. English for Specific Purposes, 13(2), 149-171.

Swales, J. M. (1995). The role of the textbook in EAP writing research. English for specific Purposes, 14(1), 3-18. 
UNIVERSITY OF CHITRAL JOURNAL OF LINGUISTICS AND LITERATURE

VOL. 5 | ISSUE II | JULY - DEC | 2021 ISSN (E): 2663-1512, ISSN (P): 2617-3611

https://doi.org/10.33195/Ill.v5ill.310

Zahra, T., \& Abbas, A. (2018). Pedagogical Implications of Corpus-Based Approaches to ELT in Pakistan. Journal of Education and Educational Development, 5(2), 259-275.

Wells, G. (1992). The centrality of talk in education. In K. Norman (Ed.), Thinking voices: The Work of the National Oracy Project. 283-310. London: Hodder and Stoughton.

Wu, G., \& Zhu, Y. (2014). Self-mention and authorial identity construction in English and Chinese research articles: A contrastive study. Linguistics \& the Human Sciences, 10(2).

\section{Appendix}

STRUCTURAL ANNOTATION OF DATA

\begin{tabular}{|l|l|l|l|l|l|}
\hline S.no & Title of Book & Name of Author & $\begin{array}{l}\text { Publication } \\
\text { Year }\end{array}$ & $\begin{array}{l}\text { Total number } \\
\text { of words }\end{array}$ & $\begin{array}{l}\text { Code } \\
\text { number }\end{array}$ \\
\hline 01 & $\begin{array}{l}\text { Corporate } \\
\text { Goverance in } \\
\text { Pakistan }\end{array}$ & $\begin{array}{l}\text { Syed Kashif Saeed, Umer } \\
\text { Faiz }\end{array}$ & 2018 & 97 & $\begin{array}{l}\text { SS-PRE- } \\
01\end{array}$ \\
\hline
\end{tabular}


UNIVERSITY OF CHITRAL JOURNAL OF LINGUISTICS AND LITERATURE VOL. 5 | ISSUE II | JULY - DEC | 2021 IISA ISN (E): 2663-1512, ISSN (P): 2617-3611 https://doi.org/10.33195/jll.v5ill.310

\begin{tabular}{|c|c|c|c|c|c|}
\hline $\mathbf{0 2}$ & $\begin{array}{l}\text { National } \\
\text { Security: } \\
\text { Imperatives and } \\
\text { Challenges } \\
\text { Through a } \\
\text { Prism of } \\
\text { International } \\
\text { Law }\end{array}$ & Ms. Beenish Sultan Qazi & 2017 & 475 & $\begin{array}{l}\text { SS-PRE- } \\
02\end{array}$ \\
\hline $\mathbf{0 3}$ & $\begin{array}{l}\text { Women in } \\
\text { Pakistan }\end{array}$ & Dr. Naima Tabassum & 2016 & 728 & $\begin{array}{l}\text { SS-PRE- } \\
03\end{array}$ \\
\hline 04 & $\begin{array}{l}\text { Economic } \\
\text { Management } \\
\text { and Emerging } \\
\text { Issues in } \\
\text { Pakistan }\end{array}$ & $\begin{array}{l}\text { Professor Dr. Mohammad } \\
\text { Aslam } \\
\text { Chaudhary }\end{array}$ & 2019 & 1712 & $\begin{array}{l}\text { SS-PRE- } \\
04\end{array}$ \\
\hline 05 & $\begin{array}{l}\text { Pakistan A } \\
\text { descriptive } \\
\text { Atlas }\end{array}$ & Rizwana Zahid Ahmed & 1999 & 291 & $\begin{array}{l}\text { SS-PRE- } \\
05\end{array}$ \\
\hline 06 & $\begin{array}{l}\text { Psychological } \\
\text { Processes }\end{array}$ & $\begin{array}{l}\text { Prof. Zarin Bukhari, Saniya } \\
\text { Sameer, Hania Shah }\end{array}$ & 2009 & 263 & $\begin{array}{l}\text { SS-PRE- } \\
06\end{array}$ \\
\hline 07 & $\begin{array}{l}\text { Economic } \\
\text { Development of } \\
\text { Pakistan }\end{array}$ & Abdul Haleem Khawja & 1995 & 277 & $\begin{array}{l}\text { SS-PRE- } \\
07\end{array}$ \\
\hline 08 & $\begin{array}{l}\text { Islamic } \\
\text { Education }\end{array}$ & M.D.Zafar & 1991 & 362 & $\begin{array}{l}\text { SS-PRE- } \\
08\end{array}$ \\
\hline 09 & $\begin{array}{l}\text { An Approach to } \\
\text { Psychology }\end{array}$ & Rakhshanda Shahnaz & 2010 & 289 & $\begin{array}{l}\text { SS-PRE- } \\
09\end{array}$ \\
\hline 10 & $\begin{array}{l}\text { Islamiyat For } \\
\text { Students }\end{array}$ & Farkhanda Noor Muhammad & 2018 & 267 & $\begin{array}{l}\text { SS-PRE- } \\
010\end{array}$ \\
\hline
\end{tabular}


UNIVERSITY OF CHITRAL JOURNAL OF LINGUISTICS AND LITERATURE VOL. 5 | ISSUE II | JULY - DEC | 2021 ISSN (E): 2663-1512, ISSN (P): 2617-3611 https://doi.org/10.33195/jll.v5ill.310

\begin{tabular}{|c|c|c|c|c|c|}
\hline 11 & $\begin{array}{l}\text { Islamic } \\
\text { Education }\end{array}$ & $\begin{array}{l}\text { A.S.Bukhari, M.D.Zafar, Dr. } \\
\text { M.Yahya, Prof. Abdul Sattar } \\
\text { Shakir, Hafiz Aitbar Khan, } \\
\text { Z.S. Bukhari }\end{array}$ & 2009 & 519 & \begin{tabular}{|l} 
SS-PRE- \\
011
\end{tabular} \\
\hline 12 & $\begin{array}{l}\text { Principles of } \\
\text { Economics II }\end{array}$ & A. Hamid Shahid & 1998 & 220 & $\begin{array}{l}\text { SS-PRE- } \\
012\end{array}$ \\
\hline 13 & Sociology & Amal sajjad, jawad tariq & 2017 & 239 & $\begin{array}{l}\text { SS-PRE- } \\
013\end{array}$ \\
\hline 14 & $\begin{array}{l}\text { General } \\
\text { Agriculture }\end{array}$ & $\begin{array}{l}\text { Dr. Muhammad Akhtar } \\
\text { Abbas }\end{array}$ & 2016 & 366 & $\begin{array}{l}\text { SS-PRE- } \\
014\end{array}$ \\
\hline 15 & Income tax law & $\begin{array}{l}\text { Dr. Zalifqar Ahmad Bowra, } \\
\text { Prof. Rifat Iqbal, Qazi } \\
\text { Shahzad Ehtesham }\end{array}$ & 2016 & 278 & $\begin{array}{l}\text { SS-PRE- } \\
015\end{array}$ \\
\hline 16 & Business law & Qazi Awais Amin & 2007 & 537 & $\begin{array}{l}\text { SS-PRE- } \\
016\end{array}$ \\
\hline 17 & $\begin{array}{l}\text { International } \\
\text { Relations }\end{array}$ & Muhammad Ikram Rabbani & 2014 & 495 & $\begin{array}{l}\text { SS-PRE- } \\
017\end{array}$ \\
\hline 18 & $\begin{array}{l}\text { Public } \\
\text { Administration }\end{array}$ & Iqra Riaz-Ud-Din & 2016 & 260 & $\begin{array}{l}\text { SS-PRE- } \\
018\end{array}$ \\
\hline 19 & $\begin{array}{l}\text { Economic } \\
\text { Development of } \\
\text { Pakistan }\end{array}$ & Shakeel Ahmed & 2020 & 137 & $\begin{array}{l}\text { SS-PRE- } \\
019\end{array}$ \\
\hline 20 & Jurisprudence & Imran A. Nyazee & 2007 & 307 & $\begin{array}{l}\text { SS-PRE- } \\
020\end{array}$ \\
\hline 21 & $\begin{array}{l}\text { Introduction to } \\
\text { Political Science }\end{array}$ & Muhammad Sarwar & 1992 & 549 & $\begin{array}{l}\text { SS-PRE- } \\
021\end{array}$ \\
\hline 22 & $\begin{array}{l}\text { Physical } \\
\text { geography }\end{array}$ & M.IFTIKHAR AKRAM CH. & 2003 & 699 & $\begin{array}{l}\text { SS-PRE- } \\
022\end{array}$ \\
\hline 23 & $\begin{array}{l}\text { Functional } \\
\text { English }\end{array}$ & $\begin{array}{l}\text { Prof.Muhammad Aslam } \\
\text { Gondal }\end{array}$ & 2008 & 366 & $\begin{array}{l}\text { SS-PRE- } \\
023\end{array}$ \\
\hline
\end{tabular}


UNIVERSITY OF CHITRAL JOURNAL OF LINGUISTICS AND LITERATURE VOL. 5 | ISSUE II | JULY - DEC | 2021 ISSN (E): 2663-1512, ISSN (P): 2617-3611 https://doi.org/10.33195/ill.v5ill.310

\begin{tabular}{|c|c|c|c|c|c|}
\hline 24 & $\begin{array}{l}\text { Business } \\
\text { Communication } \\
\text { \& Report } \\
\text { Writing }\end{array}$ & Prof. M. Hafeez-ur-Rehman & 2015 & 322 & $\begin{array}{l}\text { SS-PRE- } \\
024\end{array}$ \\
\hline 25 & $\begin{array}{l}\text { English } \\
\text { Compulsory } \\
\text { (Grade-XI) }\end{array}$ & Waheedullah & 2018 & 351 & $\begin{array}{l}\text { SS-PRE- } \\
025\end{array}$ \\
\hline 26 & $\begin{array}{l}\text { Essentials of } \\
\text { International } \\
\text { Relations }\end{array}$ & Kanwal Batool Naqvi & 2020 & 315 & $\begin{array}{l}\text { SS-PRE- } \\
026\end{array}$ \\
\hline 27 & Political Science & Shahid Mehmood & 2018 & 339 & $\begin{array}{l}\text { SS-PRE- } \\
027\end{array}$ \\
\hline 28 & Psychology & Tayab Saifullah & 2021 & 214 & $\begin{array}{l}\text { SS-PRE- } \\
028\end{array}$ \\
\hline 29 & Anthropology & Sara Khan & 2020 & 132 & $\begin{array}{l}\text { SS-PRE- } \\
029\end{array}$ \\
\hline 30 & $\begin{array}{l}\text { English } \\
\text { Jurisprudence }\end{array}$ & Muhammad Aslam Chaudhry & 2010 & 256 & $\begin{array}{l}\text { SS-PRE- } \\
030\end{array}$ \\
\hline 31 & $\begin{array}{l}\text { Police, crime } \\
\text { and Politics }\end{array}$ & Hafiz S.D. Jamy & 2005 & 220 & $\begin{array}{l}\text { SS-PRE- } \\
031\end{array}$ \\
\hline 32 & $\begin{array}{l}\text { Civics of } \\
\text { Pakistan }\end{array}$ & Muhammad Asif Malik & 2009 & 174 & $\begin{array}{l}\text { SS-PRE- } \\
032\end{array}$ \\
\hline 33 & Journalism & Safiq Baloch & 2018 & 276 & $\begin{array}{l}\text { SS-PRE- } \\
033\end{array}$ \\
\hline 34 & Education & Prof. Dr. Abdul Khaliq & 2012 & 341 & $\begin{array}{l}\text { SS-PRE- } \\
034\end{array}$ \\
\hline 35 & $\begin{array}{l}\text { Introduction to } \\
\text { Law }\end{array}$ & Imran Ahsan Khan Nyazee & 2016 & 526 & $\begin{array}{l}\text { SS-PRE- } \\
035\end{array}$ \\
\hline 36 & Journalism & Muhammad Asif Malik & 2005 & 339 & $\begin{array}{l}\text { SS-PRE- } \\
036\end{array}$ \\
\hline
\end{tabular}


UNIVERSITY OF CHITRAL JOURNAL OF LINGUISTICS AND LITERATURE VOL. 5 | ISSUE II | JULY - DEC | 2021 ISSN (E): 2663-1512, ISSN (P): 2617-3611 https://doi.org/10.33195/jll.v5ill.310

\begin{tabular}{|c|c|c|c|c|c|}
\hline 37 & $\begin{array}{l}\text { Linguistics For } \\
\text { Beginners }\end{array}$ & Tariq Rahman & 2010 & 585 & $\begin{array}{l}\text { SS-PRE- } \\
037\end{array}$ \\
\hline 38 & $\begin{array}{l}\text { Economic } \\
\text { theory }\end{array}$ & Abdul Haleem Khawaja & 2007 & 383 & $\begin{array}{l}\text { SS-PRE- } \\
038\end{array}$ \\
\hline 39 & Education & Dr. Khalid Rashid & 2010 & 281 & $\begin{array}{l}\text { SS-PRE- } \\
039\end{array}$ \\
\hline 40 & Gender Studies & M. Nawaz Khalid Aarbi & 2021 & 324 & $\begin{array}{l}\text { SS-PRE- } \\
040\end{array}$ \\
\hline 41 & $\begin{array}{l}\text { Essentials of } \\
\text { Home } \\
\text { Economics }\end{array}$ & Prof. Matina Zia & 2012 & 378 & $\begin{array}{l}\text { SS-PRE- } \\
041\end{array}$ \\
\hline 42 & $\begin{array}{l}\text { International } \\
\text { Relations }\end{array}$ & M. Safdar Mullick & 2015 & 375 & $\begin{array}{l}\text { SS-PRE- } \\
042\end{array}$ \\
\hline 43 & $\begin{array}{l}\text { An introduction } \\
\text { to Gender } \\
\text { Studies }\end{array}$ & $\begin{array}{l}\text { Samraiz Hafeez, Waheed } \\
\text { Khan, } \\
\text { Humaira Tehsin }\end{array}$ & 2020 & 336 & $\begin{array}{l}\text { SS-PRE- } \\
043\end{array}$ \\
\hline 44 & Journalist & Abid Tehami & 1997 & 289 & $\begin{array}{l}\text { SS-PRE- } \\
044\end{array}$ \\
\hline 45 & Political Science & M. Aslam Chaudhary & 2008 & 269 & $\begin{array}{l}\text { SS-PRE- } \\
045\end{array}$ \\
\hline 46 & $\begin{array}{l}\text { Public } \\
\text { Administration }\end{array}$ & Dr. Sultan Khan & 2006 & 305 & $\begin{array}{l}\text { SS-PRE- } \\
046\end{array}$ \\
\hline 47 & $\begin{array}{l}\text { Labour and } \\
\text { Taxation law }\end{array}$ & Saima Pervaiz Butt & 2000 & 141 & $\begin{array}{l}\text { SS-PRE- } \\
047\end{array}$ \\
\hline 48 & $\begin{array}{l}\text { Business } \\
\text { Communication }\end{array}$ & Shakeel Amjad & 2010 & 359 & $\begin{array}{l}\text { SS-PRE- } \\
048\end{array}$ \\
\hline 49 & $\begin{array}{l}\text { Health and } \\
\text { Physical } \\
\text { Education }\end{array}$ & Prof. Muhammad Altaf & 2020 & 533 & $\begin{array}{l}\text { SS-PRE- } \\
049\end{array}$ \\
\hline
\end{tabular}


UNIVERSITY OF CHITRAL JOURNAL OF LINGUISTICS AND LITERATURE

VOL. 5 | ISSUE II | JULY - DEC | 2021 G $=1$ II) ISSN (E): 2663-1512, ISSN (P): 2617-3611

https://doi.org/10.33195/Ill.v5ill.310

\begin{tabular}{|l|l|l|l|l|l|}
\hline 50 & $\begin{array}{l}\text { Business } \\
\text { Communication }\end{array}$ & Hafeez ur Rehman & 2010 & 138 & $\begin{array}{l}\text { SS-PRE- } \\
050\end{array}$ \\
\hline
\end{tabular}

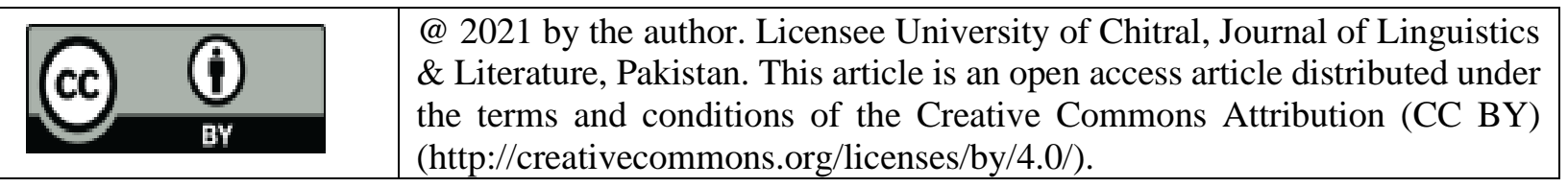

